\title{
Basics of forming the functional literacy of schoolchildren
}

\section{Noções básicas de formação da alfabetização funcional de crianças em idade escolar}

\section{Conceptos básicos para formar la alfabetización funcional de los escolares}

\author{
Marina A. Khudyakova1 ${ }^{\text {iD }}$, Irina N. Vlasova ${ }^{1}$ iD, Larisa V. Selkina ${ }^{1}$ iD, \\ Anna V. Hudyakova1 ${ }^{1}$, Svetlana V. Shustova ${ }^{2}$ iD \\ ${ }^{1}$ Perm State Humanitarian Pedagogical University, Perm, Russia. \\ 2 Perm State National Research University, Perm, Russia. \\ Corresponding author: \\ Marina A. Khudyakova \\ Email:mamigx@pspu.ru
}

How to cite: Khudyakova, M. A., Vlasova, I. N., Selkina, L. V., Hudyakova, A. V., \& Shustova, S. V. (2021). Basics of forming the functional literacy of schoolchildren. Revista Tempos e Espaços em Educação, 14(33), e16757.

http://dx.doi.org/10.20952/revtee.v14i33.16757

\begin{abstract}
The article examines the formation of information skills as an integral part of the student's functional literacy in conformity with both international and Russian studies. Its conclusions are based both on the analysis of these studies (the content of tasks, the results of diagnosis) and on specific features of federal educational standards and educational and methodological publications concerned with the development of information skills. In the course of the research, the authors have revealed that the formation of information skills in students is influenced not so much by the choice of textbooks but by the teacher's work, use of techniques, means and methods of organizing the activities aimed at mastering all the skills listed in federal state educational standards in relation to data processing. The conditions influencing the achievement of the planned results in mastering the educational program related to the search and transformation of information as an integral part of the functional literacy of schoolchildren are as follows: work with continuous and non-continuous texts.
\end{abstract}

Keywords: Functional literacy. Data processing. Information skills. Continuous and non-continuous text. Metadisciplinary skills. Primary and secondary schoolchildren.

\section{RESUMO}

O artigo examina a formação de habilidades de informação como parte integrante da alfabetização funcional do aluno em conformidade com os estudos internacionais e russos. Suas conclusões baseiam-se na análise desses estudos (o conteúdo das tarefas, os resultados do diagnóstico) e nas 
características específicas das normas educacionais federais e das publicações educacionais e metodológicas voltadas para o desenvolvimento das habilidades de informação. No decorrer da pesquisa, os autores revelaram que a formação de habilidades informacionais nos alunos é influenciada não tanto pela escolha dos livros didáticos, mas pelo trabalho do professor, uso de técnicas, meios e métodos de organização das atividades visando o domínio de todos. as habilidades listadas nas normas educacionais estaduais federais em relação ao processamento de dados. As condições que influenciam o alcance dos resultados planejados no domínio do programa educacional relacionado à busca e transformação da informação como parte integrante da alfabetização funcional de escolares são as seguintes: trabalhar com textos contínuos e não contínuos.

Palavras-chave: Alfabetização funcional. Processamento de dados. Habilidades de informação. Texto contínuo e não contínuo. Competências metadisciplinares. Alunos do ensino fundamental e médio.

\section{RESUMEN}

El artículo examina la formación de habilidades de información como parte integral de la alfabetización funcional del estudiante de conformidad con los estudios internacionales y rusos. Sus conclusiones se basan tanto en el análisis de estos estudios (el contenido de las tareas, los resultados del diagnóstico) como en las características específicas de los estándares educativos federales y las publicaciones educativas y metodológicas relacionadas con el desarrollo de las habilidades de información. En el curso de la investigación, los autores han revelado que la formación de habilidades de información en los estudiantes está influenciada no tanto por la elección de los libros de texto sino por el trabajo del docente, el uso de técnicas, medios y métodos de organización de las actividades destinadas a dominar todos. las habilidades enumeradas en los estándares educativos del estado federal en relación con el procesamiento de datos. Las condiciones que influyen en el logro de los resultados planificados en el dominio del programa educativo relacionado con la búsqueda y transformación de la información como parte integral de la alfabetización funcional de los escolares son las siguientes: trabajar con textos continuos y discontinuos.

Palabras clave: Alfabetización funcional. Procesamiento de datos. Habilidades de información. Texto continuo y discontinuo. Habilidades metadisciplinarias. Alumnos de primaria y secundaria.

\section{INTRODUCTION}

In the current education system, we need to consider the issues of preparing students for effective functioning in a rapidly changing information environment, drastic social changes, their future professional activity and life in general, which requires the formation of certain skills and functional literacy.

According to the Decree of the President of the Russian Federation of July 21, 2020 No. 474 "On the national development goals of the Russian Federation for the period up to 2030" and the national goal "Opportunities for self-realization and talents development", a priority area of the national project "Education" is designated, i.e. to ensure global competitiveness of the Russian education and promote the Russian Federation into the top 10 countries in terms of the quality of general education (Ukaz o natsionalnykh tselyakh razvitiya Rossii do 2030 goda, 2020).

The effectiveness of any education system in global terms is realized through the fulfillment of international educational standards by students, where one of the main indicators is the student's functional literacy.

Approaches to the formation of functional literacy, its manifestation and components have been the research subject of foreign scholars for several decades (Street, 2013; Hamilton \& Burgess, 
2013). UNESCO's report "Education for All" emphasized the global importance of functional literacy (Education for all: Global monitoring report 2015: Achievements and challenges, 2015).

According to the Russian scholars, functional literacy becomes a factor contributing to the participation of any person in social, cultural, economic and other spheres of activity. Functional literacy is considered as a necessary condition for living, for example, in a cultural environment since it manifests itself in a specific situation, therefore it can be presented as a goal of human activity (Kruse, 2021).

The study aims at determining teaching methods that allow the formation of data processing skills as the basis of the functional literacy of students.

Functional literacy is understood as the ability of a person to use the knowledge acquired during their life to solve a wide range of tasks in various spheres of human activity, communication and social relations (Leontev, 2016, p. 35). Accordingly, N.F. Vinogradova (2018) defined a functionally literate person as a person who is capable of "using all knowledge, skills and abilities acquired throughout their life to solve the widest possible range of tasks in various spheres of human activity, communication and social relations".

Functional literacy comprises communication (including reading), mathematical and natural science literacy. However, the structure of functional literacy was expanded by PISA (Programme for International Student Assessment) in 2018, where global competence (as an ability of students to interact with the outside world) was designated as an object of verification.

While relying on international comparative studies in the field of education, V.S. Basyuk and G.S. Kovaleva expressed an idea that "the Russian students are good at mastering disciplinary knowledge at the level of its reproduction or use in a familiar educational situation but they have difficulties in applying this knowledge in unfamiliar situations that are closer to real life" (Basyuk \& Kovaleva, 2019, p. 14). The reasons might be as follows: the lack of study time in the classroom, which does not allow to pay much attention to practice-oriented tasks and life situations; the lack of didactic, educational and methodological materials; the unreadiness of teachers (motivational, theoretical, subject-related and methodological) for forming the functional literacy of schoolchildren (Kautz, 2014). In addition, we can mention one more reason, i.e. the level and quality of information skills among students. The relevant practice shows that students (especially junior schoolchildren) do not know how to navigate the information flow, highlight the main and the secondary, experience difficulties in formulating questions, finding the necessary information, systematizing and transforming it, as well as using modern software to analyze information sources. Consequently, the ability to work with information can be both the basis and the manifestation of the student's functional literacy.

Such a concept as "the ability to work with information" is closely related to the concepts of "information literacy", "information competence" and "information culture".

Information culture is a systemic ability to purposefully work with information and receive it, process and transmit, as well as apply computer information technologies, modern technical means and methods (Zenkin, 2013, p. 16). Information competence is an integrated concept of information literacy and culture that includes the ability to carry out information activities. O.K. Gromova considered information literacy as the ability to form an information need, to request, search, select, evaluate and process data in any form (Gromova, 2013, p. 42).

P.N. Novikov, O.F. Seliverstiva and I.F. Chaplygin claimed that information literacy is the person's ability to realize the need for information, effectively search for it, analyze and use it (Novikov et al., 2006, p. 10). Consequently, information literacy is an integral part of information competence and its core is the ability to work with information, whose level affects the formation of information literacy, culture and functional literacy, as well as competence in general. 
In the draft of the new edition of federal state educational standards for primary general education, the ability to work with information was placed in a separate group of metadisciplinary results (Proekt Prikaza Minprosveshcheniya Rossii, 2019, p. 35).

In the standard approved by the Decree of the Ministry of Education of the Russian Federation in 2021, data processing is classified as a cognitive universal educational activity (like in the second generation standard of 2009) and includes the ability to: select a source of information; find explicit information in the proposed source according to the given algorithm; to recognize reliable and inaccurate information independently or based on the method of its verification proposed by pedagogical workers, etc. (Prikaz Ministerstva prosveshcheniya Rossiiskoi Federatsii № 286, 2021, p. 34).

\section{MATERIALS AND METHODS}

While considering the foundations of functional literacy, we have determined information skills that serve as the basis for the formation of universal competences. The material was one's ability to work with information enshrined in a basic educational program ( 24 skills) and educational standards (from five to eight skills). We also demonstrated how these skills are presented in regulatory documents and educational publications, as well as used in diagnostic materials in Russia and foreign countries. As a result, we have realized that not all information skills are purposefully developed in the process of studying academic disciplines since practical and methodological recommendations do not contain special tasks and techniques for working with educational and cognitive information to form basic functional literacy, i.e. data processing skills. These skills and methods of their formation were studied using the following methods: comparative analysis, observation, induction, interpretation, testing and mathematical statistics. The research was carried out in three stages: 1 ) the skills of working with information that underlie the formation of the functional literacy among schoolchildren were highlighted and described; 2) means, approaches and techniques for forming information skills were determined; 3 ) the effectiveness of the proposed approaches was substantiated using the methods of mathematical statistics.

\section{RESULTS AND DISCUSSION}

The comparative analysis of new standards for primary and secondary schools (2021) has proved that data processing skills are included in the structure of universal educational cognitive actions, which reveals continuity in the formation of information skills among students.

Since 1995 an international comparative monitoring of the quality of mathematical and natural science education TIMSS (Trends in Mathematics and Study) has been carried out in Russia. Its results allow to trace not only the mastery of various cognitive activities ("knowledge", "application" and "reasoning" in these areas) but also the development of data processing skills. A typical basic task is to read a ready-made bar chart and extract the necessary information from it. The result in Russia averaged 91\%, which is higher than aggregate figures in other countries (84\%). When performing another type of tasks on the diagram (to correlate the numerical data from the table with the existing columns in the diagram and supplement it), the younger students experienced certain difficulties. This testifies to the lack of their data processing skills, which means that the functional literacy of primary and secondary schoolchildren is insufficient. The reason is the unsystematic inclusion of information-related tasks in the Russian textbooks. While considering the results of the TIMSS study, O.A. Rydze and other scholars described two more groups of issues: when students lack subject skills to complete a task and universal actions, including data processing skills (Rydze, 2017; Tymss, 2013).

Other studies also prove that the Russian programs pay little attention to the formation of functional literacy, including its natural science component, and are more focused on the acquisition 
and application of subject knowledge. Therefore, schoolchildren show low results in completing TIMSS and PISA tasks (Program for International Student Assessment), in which the emphasis is on the application of knowledge and skills, as well as the mastery of universal actions: planning and data interpretation (Pentin et al., 2018; Poropat, 2009).

To assess how metadisciplinary actions (in particular, the ability to work with information) can influence the formation of students' functional literacy (the use of acquired knowledge, skills and abilities to solve life tasks), we conducted a comparative analysis of metadisciplinary (work with information) and disciplinary results indicated in the sample educational programs for primary school. It is partially presented in Table 1.

Table 1. The comparative analysis of metadisciplinary (data processing) and disciplinary results in primary school

\begin{tabular}{|c|c|}
\hline Metadisciplinary results & Disciplinary results \\
\hline $\begin{array}{l}\text { To select the source of } \\
\text { information }\end{array}$ & $\begin{array}{l}\text { The Russian language } \\
\text { To identify words in speech, whose meaning requires clarification; to } \\
\text { determine the meaning of a word in text or clarify it using an explanatory } \\
\text { dictionary. } \\
\text { To use special and reference books, dictionaries, newspapers, magazines and } \\
\text { the Internet. } \\
\text { Literature } \\
\text { To be able to explain the meaning of an unfamiliar word based on context, } \\
\text { using dictionaries and other sources of information. } \\
\text { To select books and magazines to read independently or on the advice of an } \\
\text { adult. } \\
\text { To be able to use reference books for additional information in accordance } \\
\text { with the educational task. } \\
\text { The world around us } \\
\text { To be able to find the necessary information in natural science texts or the } \\
\text { Internet for answering questions, explaining and creating oral or written } \\
\text { messages about the nature of the Earth, Russia and native land. } \\
\text { To use various reference books, children's literature and the Internet to extract } \\
\text { cognitive information in order to answer questions, provide explanations and } \\
\text { prepare messages about the life of society in the past, present and future. }\end{array}$ \\
\hline $\begin{array}{l}\text { To find explicit information in } \\
\text { the proposed source according } \\
\text { to any given algorithm }\end{array}$ & $\begin{array}{l}\text { Literature } \\
\text { To understand the semantic content of educational texts; to use selective } \\
\text { reading to find the necessary material; to find explicit information in text. } \\
\text { To draw simple conclusions based on the information contained in text; to } \\
\text { interpret and summarize this information; to analyze and evaluate content. } \\
\text { Mathematics } \\
\text { To solve educational and practical text tasks related to everyday life, to suggest } \\
\text { different ways to solve them, if any, to choose a rational solution, including for } \\
\text { tasks with redundant data, to find missing information in tables, diagrams, } \\
\text { etc.; to record redundant information. }\end{array}$ \\
\hline $\begin{array}{l}\text { To use diagrams and tables to } \\
\text { present information; to create } \\
\text { diagrams and tables for } \\
\text { presenting } \\
\text { independently }\end{array}$ & $\begin{array}{l}\text { The Russian language } \\
\text { To correlate the structure of a word with the presented diagram. } \\
\text { Mathematics } \\
\text { To structure information, work with tables, diagrams and graphical charts, } \\
\text { extract the necessary data, fill out ready-made forms, present, analyze and } \\
\text { interpret data, draw conclusions using structured information: to structure } \\
\text { information using tables, diagrams and drawings, enter data into a table, fill } \\
\text { out diagrams and drawings with numerical data; to extract the information } \\
\text { presented in the simplest column/bar charts, the simplest tables with data on } \\
\text { real processes and phenomena of the surrounding world (including a calendar } \\
\text { or schedule), in everyday objects (a tag, label, account, menu, price list, } \\
\text { announcement, etc.) and use it for solving tasks. }\end{array}$ \\
\hline
\end{tabular}




\begin{tabular}{|l|l|}
\hline Metadisciplinary results & Disciplinary results \\
\hline & $\begin{array}{l}\text { The world around us } \\
\text { To have an idea about the physical map of Russia and the designation of } \\
\text { natural objects on it. }\end{array}$ \\
\hline $\begin{array}{l}\text { To analyze and create text, } \\
\text { video, graphic, sound } \\
\text { information in conformity with } \\
\text { an educational task }\end{array}$ & $\begin{array}{l}\text { Literature } \\
\text { To correlate verbal creative works with other types of arts (painting, music, } \\
\text { photography and cinema). } \\
\text { The world around us } \\
\text { To recognize and describe regional symbols, to explain their meaning; to know } \\
\text { the unique cultural monuments and sights of Russia, describe them using } \\
\text { illustrations; to be able to describe the natural community and the relationship } \\
\text { of organisms (food chain) based on independently selected illustrations. }\end{array}$ \\
\hline
\end{tabular}

The comparative analysis has revealed that:

Firstly, not every ability to work with information from federal educational standards of primary education is related to disciplinary results. For example, no correspondence was found between the results "Selecting a source of information" and the "Mathematics" discipline; "Compliance with information security rules in everyday life situations and the Internet" and the "Russian language" discipline;

Secondly, the formation of data processing skills can affect the level of academic achievements since many of the skills listed above are associated with disciplinary results: "the selection of the source of information" is associated with disciplinary results in such subjects as "The Russian language" and "The world around us"; "the compliance with information security rules in everyday life and when working on the Internet" is associated with disciplinary results in "Mathematics" and "The world around".

Based on the above, there is a connection between the skills indicated in the block "Working with information" and disciplinary results, therefore, purposeful work on the formation of information skills can have a positive effect on the acquisition of subject knowledge, skills, abilities and their use for solving life problems, which is the core of students' functional literacy.

The ability to work with information is formed during lessons in primary school through textbooks (pictures, drawings, tables, graphs, diagrams, bar charts, etc.), teaching aids, presentations, video and audio materials.

It is worth mentioning that the above-mentioned means of forming data processing skills are simultaneously sources of information, i.e. they have a dual character. For example, a textbook is a source of information as it contains material necessary to learn something new. A book also serves as a teaching tool since it is a structured educational publication containing specially selected and systematized scientific and theoretical data presented in a convenient form for study and assimilation. In relation to teaching aids, a book can likely realize developmental and educational functions in a person.

The analysis of PIRLS (Progress in International Reading Literacy Study), in which the Russian fourth-graders participated, has detected a high level of their reading skills that help to understand fictional and information texts. However, the study revealed that the ability to find explicit information in texts and interpret it are shortcomings of the Russian fourth-graders. Thus, one of the directions for the development of reading literacy as a component of functional literacy is the search for new pedagogical approaches and teaching methods (Zuckerman, 2016).

Let us consider the formation of data processing skills as the basis of functional literacy as exemplified by teaching mathematics in primary school. Since primary education has a variable character and uses different textbooks in the educational process, we also determined the dependence of information skills on the choice of a particular textbook. The study comprised second-graders (92 students) of Perm educational organizations whose use such mathematics textbooks as "The School of Russia" (the author is M.I. Moro et al. (2015), D.B. Elkonin - V.V. 
Davydov's system (the authors are V.V. Davydov \& S.F. Gorbov) (Davydov, 2008), "The Planet of Knowledge" (the authors are M.I. Bashmakov \& M.G. Nefedova (2018)).

Primary schoolchildren were asked to perform several tasks to evaluate the formation of their skills: to find explicit information in a text, transform this text information into a table, organize data and determine their reliability.

To process the results obtained, we used the means of mathematical statistics: the average score for each class, median, variance, intergroup variance and Cramer-Welch's test. While considering these results, we have drawn the following conclusions: the average score for three classes is practically the same and the intergroup variance is close to zero. The comparison of the empirical value of Cramer-Welch's test with the critical one $\left(T_{e m p} \leq 1.96\right)$ shows that the typical features of the compared samples coincide at a significance level of 0.05 , i.e. all the students have approximately the same level of data processing skills. Consequently, the formation of students' information skills is influenced not so much by the choice of a textbook as by the teacher's work, use of techniques, means and methods of organizing student activities aimed at mastering all the skills listed in the second-generation standards of working with information.

As a means of developing data processing skills, we need to consider the tasks compiled based on continuous and non-continuous texts presented in mathematics textbooks and tasks with a metasubject component.

Continuous texts are understood as homogeneous texts of different types and genres: description, narration or reasoning (Logvina, 2012, p. 18). For example, continuous texts in mathematics include verbal tasks that provide help, rules and notes from the history of mathematics, as well as information in the "For the Curious" section.

Discontinuous texts are texts in which information is presented in a non-verbal or not only verbal way (graphs, diagrams, bar charts, tables, geographical maps, tickets, advertising brochures and posters, newspapers, magazines, etc.) (Logvina, 2012, p. 18).

To determine the nature of tasks and exercises based on continuous and non-continuous texts, we analyzed mathematics textbooks for the third grade. The selected textbooks for primary school meet the requirements of federal standards for primary education, are presented in the list of approved textbooks and are actively used by teachers.

According to the method of systemic analysis, the following criteria were identified for analyzing school textbooks:

- Topics dedicated to data processing (formulation, quantity);

- The number of tasks based on continuous texts aimed at the formation of data processing skills;

- The number of tasks based on non-continuous texts aimed at the formation of data processing skills.

As a result of the analysis, the following data were obtained:

Under the section "Mathematics on checkered paper" in a textbook within the series "The Planet of Knowledge" (the authors are M.I. Bashmakov \& M.G. Nefedova (2018)), students get acquainted with the topic "Learning diagrams" where they work with tables and diagrams. In the section "Divide into parts", they are introduced to pie charts. The ability to work with tables, figures and diagrams is formed through separate exercises distributed throughout the mathematics textbook and included in the other sections: "Numbers and quantities", "Arithmetic operations", "Geometric quantities", "Working with word problems", "Spatial relationships. Geometric figures" (Bashmakov \& Nefedova, 2018).

A textbook from the series "The School of Russia" (the authors are M.I. Moro and M.A. Bantova (2015)) and mathematics textbooks based on D.B. Elkonin - V.V. Davydov's system (the authors are V.V. Davydov and S.F. Gorbov (Davydov, 2008)) have no independent section "Working with information". This material is studied within the other sections: "Numbers and quantities", 
"Arithmetic operations", "Geometric quantities", "Working with word problems", "Spatial relations. Geometric figures", and are presented as separate exercises based on continuous or noncontinuous texts (Moro et al., 2015). The difference between tasks in V.V. Davydov's and S.F. Gorbov's mathematics textbooks is that they all are based on continuous or non-continuous texts (Davydov, 2008).

A similar situation can be seen in textbooks from the series "Perspective" (the author is L.G. Peterson). The content of this mathematics course does not highlight topics devoted to working with information but throughout all the sections in three parts of the textbook provide tasks based on continuous and non-continuous texts that contribute to the formation of the ability to work with information. About $50 \%$ of tasks present information in the form of tables, diagrams and algorithms (Peterson, 2014).

The number of tasks based on continuous and non-continuous texts in the mathematics textbooks under consideration is presented in Figure 1.

Figure 1. The number of tasks based on continuous and non-continuous texts in mathematics textbooks for the 3rd grade

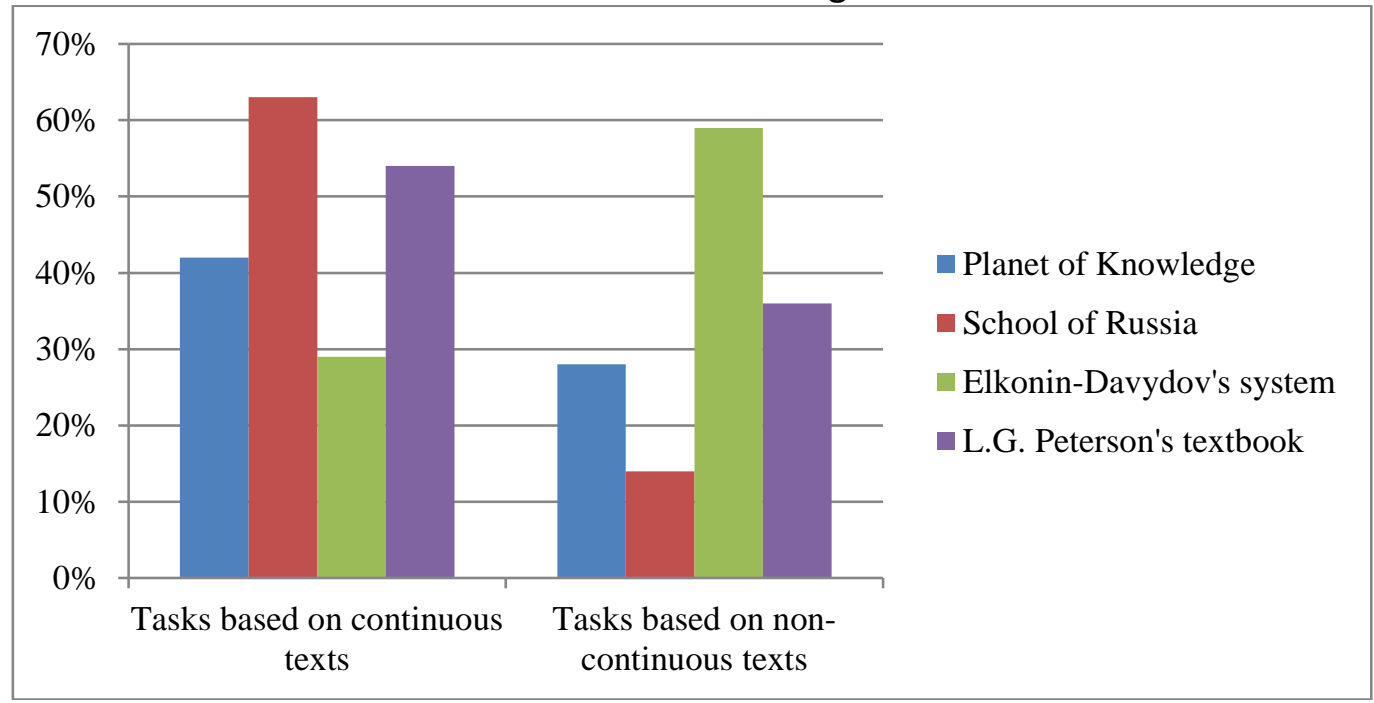

Thus, the analysis has shown that all the textbooks contain tasks for working with continuous and non-continuous texts. Under the series "The Planet of Knowledge", exercises are practiceoriented and have different levels of difficulty. Textbooks in the series "The School of Russia" offer few tasks that are practically the same, as a rule, to compile direct or indirect tasks based on a given picture. The ability to work with tables is underdeveloped since it only includes filling in one or two lines according to a given rule and does not provide for any additional work. Most of such tasks are based on continuous texts in the form of basic word problems.

In comparison with the above-mentioned textbooks, manuals based on D.B. Elkonin - V.V. Davydov's system and guide books from the series "Perspective" are quite different as they include a large number of tasks based on non-continuous texts. There are multilevel exercises based on schemes, according to which students compose a task and supplement it with the necessary information. However, these tasks do not achieve all the planned results of working with information established by standards of the second generation. Thus, teachers need to supplement the system of educational tasks to achieve their requirements. The Russian scholars confirm the need to include such tasks in school disciplines. In this regard, we have substantiated the need to form the ability to ask questions, find and evaluate information, specify and generalize it to perform a full-fledged research activity (Bezukladnikov, 2019).

After analyzing the data obtained using diagnostic methods, we can state that the general level of data processing skills in the experimental group increased in comparison with the control 
group. Thus, the use of additional techniques for working with continuous and non-continuous texts in the process of studying disciplines contributes to the formation of data processing skills. The systematic use of these tasks is particularly effective for forming the abilities to work with information.

\section{CONCLUDING OBSERVATIONS}

The main conclusions reached in this study are as follows:

- Based on regulatory documents and scientific articles, we have determined the main skills for data processing as the basis for forming the functional literacy of schoolchildren;

- The existing school textbooks contain tasks for forming data processing skills but their small number and uniformity do not contribute to the formation of the entire complex of the relevant skills under the requirements of federal state educational standards;

- We have substantiated the need to include special exercises based on continuous and noncontinuous texts into the study of each academic discipline.

\section{CONCLUSION}

The theoretical analysis of psychological, pedagogical and methodological literature on the research topic, as well as regulatory documents, allowed to determine a system of skills for data processing which are the basis for forming the student's functional literacy. While considering a variety of skills, we have selected the key ones in accordance with the requirements of general educational standards.

The analysis of modern approaches and teaching techniques has revealed certain mechanisms. Their systematic and purposeful use aims not only at mastering subject knowledge and skills but also at achieving metadisciplinary results related to the search, selection, processing, presentation, interpretation and transformation of information. Tasks with continuous and noncontinuous texts contribute to the development of information skills and increase the level of students' functional literacy.

Further research might consist in improving and identifying new approaches for forming the functional literacy of students.

Authors' Contributions: Khudyakova, M. A.: conception and design, acquisition of data, analysis and interpretation of data, drafting the article, critical review of important intellectual content. Vlasova, I. N.: conception and design, acquisition of data, analysis and interpretation of data, drafting the article, critical review of important intellectual content. Selkina, L. V.: conception and design, acquisition of data, analysis and interpretation of data, drafting the article, critical review of important intellectual content. Hudyakova, A. V.: conception and design, acquisition of data, analysis and interpretation of data, drafting the article, critical review of important intellectual content. Shustova, S. V.: conception and design, acquisition of data, analysis and interpretation of data, drafting the article, critical review of important intellectual content. All authors have read and approved the final version of the manuscript.

Ethics Approval: Not applicable.

Acknowledgments: The article was prepared within the framework of the applied research project "Conditions for the development of functional literacy among students within the implementation of primary educational programs" under an agreement concluded between the Ministry of Education of the Russian Federation and the Perm State Humanitarian-Pedagogical University.

\section{REFERENCES}

Bashmakov, M.I., Nefedova, M.G. (2018). Matematika: 3 klass [Mathematics. The 3rd grade]. Moscow: AST: Astrel.

Basyuk, V.S., Kovaleva, G.S. (2019). Innovatsionnyi proekt Ministerstva prosveshcheniya "Monitoring formirovaniya funktsionalnoi gramotnosti": osnovnye napravleniya i pervye rezultaty [The innovative project of the Ministry of 
Education of the Russian Federation "Monitoring the formation of functional literacy": the main directions and first results]. Otechestvennaya i zarubezhnaya pedagogika, 1(4(61)), 13-33.

Bezukladnikov, K.E., Kruse, B.A., Melekhina, E.S. (2019). Uchebnoe issledovanie kak sredstvo formirovaniya uchebnopoznavatelnoi kompetentnosti obuchayushchikhsya mladshego podrostkovogo vozrasta na urokakh angliiskogo yazyka [School research as a means forming the learning and cognitive competence of primary schoolchildren during English lessons]. Yazyk i kultura, 48, 259-276. DOI: 10.17223/19996195/48/17.

Davydov, V.V., Gorbov, S.F., Mikulina, G.G., Saveleva, O.V. (2008). Matematika: Uchebnik dlya 3 klassa nach. shkoly (Sistema D.B. Elkonina - V.V. Davydova) [Mathematics: textbook for the 3rd grade of primary school (D.B. Elkonin-V.V. Davydova's system)]. Moscow: "VITA-PRESS".

Education for all: Global monitoring report 2015: Achievements and challenges. (2015). Paris: UNESCO. Retrieved from: http://unesdoc.unesco.org/images/0023/002322/232205e.pdf

Gromova, O. (2013). Razvitie informatsionnoi gramotnosti shkolnikov: problemy i podkhody [Developing the information literacy of schoolchildren: issues and approaches]. Bibliotekovedenie, 2, 39-45. Retrieved from: https://bibliotekovedenie.rsl.ru/jour/article/view/852

Hamilton, M., Burgess, A. (2013). Back to the future?: functional literacy and the new skills agenda. Discussion paper. Retrieved from: http://eprints.lancs.ac.uk/66608/

Kautz, T., Heckman, J.J., Diris, R., Weel, B.T., Borghans, L. (2014). Fostering and measuring skills: Improving cognitive and non-cognitive skills to promote lifetime success. National Bureau of Economic Research, pp. 8696 pp. Retrieved from: www.nber.org/papers/w20749

Kruse, B.A., Bezukladnikov, K.E., Vertyanova A.A. (2021). Usloviya razvitiya funktsionalnoi gramotnosti: Pushkin-tsentr kak platsdarm dlya ekspansii russkogo yazyka v blizhnem i dalnem zarubezhe [The conditions for developing functional literacy: the Pushkin State Russian Language Institute as a stepping stone for the Russian language expansion to CIS and non-CIS countries]. Yazyk i kultura, 53, 190-216. DOI: 10.17223/19996195/53/13.

Leontev, A.A. (2016). Pedagogika zdravogo smysla [The pedagogics of common sense]. Moscow: Smysl.

Logvina, I., Rozhdestvenskaya, L. (2012). Formirovanie navykov funktsionalnogo chteniya. Kniga dlya uchitelya [Forming the skills of functional reading]. Tartu: Tartu Ulicool.Narva Kolledz.

Moro, M.I., Bantova, M.A., Beltyukova, G.V. (2015). Matematika. 3 klass: Uchebnik dlya obshcheobrazovatelhykh organizatsii [Mathematics. The 3rd grade: Textbook for general education institutions]. Moscow: Prosveshchenie.

Novikov, D.A. (2004). Statisticheskie metody v pedagogicheskikh issledovaniyakh (tipovye sluchai) [Statistical methods in pedagogical studies (typical cases)]. Moscow: MZ-Press.

Novikov, P.N., Seliverstiva, O.F., Chaplygina, I.F. (2006). Metodika formirovaniya klyuchevykh kompetentsii studentov kolledzha [The methods for forming the key competences of college students]. Professionalnoe obrazovanie, 2, 10-11.

Pentin, A.Yu., Kovaleva, G.S., Davydova, E.I., Smirnova, E.S. (2018). Sostoyanie estestvennonauchnogo obrazovaniya v rossiiskoi shkole po rezultatam mezhdunarodnykh issledovanii TIMSS i PISA [The state of natural sciences education in the Russian school according to the TIMSS and PISA studies]. Voprosy obrazovaniya, 1, 79-109. DOI: 10.17323/18149545-2018-1-79-109.

Peterson, L.G. (2014). Matematika: 3 klass [Mathematics: The 3rd grade]. Moscow: "Yuventa".

Poropat, A.E. (2009). A meta-analysis of the five-factor model of personality and academic performance. Psychological Bulletin, 135(2), 322-338. Retrieved from: https://psycnet.apa.org/doiLanding?doi=10.1037\%2Fa0014996

Prikaz Ministerstva prosveshcheniya Rossiiskoi Federatsii № 286 [Decree of the Ministry of Education of the Russian Federation No. 286] (May 31, 2021). "Ob utverzhdenii federalnogo gosudarstvennogo obrazovatelnogo standarta nachalnogo obshchego obrazovaniya" ["On establishing the federal state educational standard of primary general education"]. Retrieved from: http://publication.pravo.gov.ru/Document/View/0001202107050028

Proekt Prikaza Minprosveshcheniya Rossii [Draft Order of the Ministry of Education of the Russian Federation]. (2019). "Ob utverzhdenii federalnogo gosudarstvennogo obrazovatelnogo standarta nachalnogo obshchego obrazovaniya (FGOS NOO)" (izvlechenie iz proekta dokumenta) ["On establishing the federal state educational standard of primary general education" (as extracted from the draft document)]. Retrieved from:

http://www.consultant.ru/law/hotdocs/57358.html 
Rydze, O.A. (2017). Learners' achievements in mathematical information processing at primary school. The European Proceedings of Social \& Behavioural Scieces (EpSBS), Moscow, Russia, 07-08 June 2017. Moscow: Future Academy Future Academy, pp. 512-522. DOI: 10.15405/epsbs.2017.08.60.

Street, B.V. (2013). Literacy in Theory and Practice: Challenges and Debates Over 50 Years. Theory into Practice, 52(suppl. 1), P. 52-62. Retrieved from: https://www.tandfonline.com/doi/abs/10.1080/00405841.2013.795442

Tymms, P., Merrell, C., Hawker, D., Nicholson, F. (2014). Performance Indicators in the Primary Schools: A comparison of performance on entry to school and the progress made in the first year in England and four other jurisdictions: Research report. Retrieved from: https://www.gov.uk/government/publications/performance-indicators-in-primaryschools

Ukaz o natsionalnykh tselyakh razvitiya Rossii do 2030 goda [Decree on the national development goals of Russia up to 2030]. (2020). Retrieved from: https://strategy24.ru/rf/news/ukaz-o-natsionalnykh-tselyakh-razvitiya-rossii-do-2030goda

Vinogradova, N.F. (2018). Teaching at the Modern Russian Primary School: Pros and Cons. Espacios, 39, 7.

Vinogradova, N.F., Kochurova, E.E., Kuznetsova, M.I. (2018). Funktsionalnaya gramotnost mladshego shkolnika: kniga dlya uchitelya [The functional literacy of primary schoolchildren]. Moscow: Rossiiskii uchebnik: Ventana-Graf.

Zenkin, O.N. (2013). Problemy razvitiya informatsionnoi kultury v protsesse informatizatsii obrazovaniya [The development of information culture in the process of education informatization]. Psikhologo-pedagogicheskii zhurnal Gaudeamus, 2, 15-18.

Zuckerman, G.A., Kovaleva, G.S., Baranova, V.Yu. (2018). Chitatelskie umeniya rossiiskikh chetveroklassnikov: uroki PIRLS-2016 [The reading skills of fourth-graders in Russia: PIRLS-2016 lessons]. Voprosy obrazovaniya, 1, 58-78. DOI: 10.17323/1814-9545-2018-1-58-78.

Received: 1 June 2021 | Accepted: 16 September 2021 | Published: 18 November 2021

This is an Open Access article distributed under the terms of the Creative Commons Attribution License, which permits unrestricted use, distribution, and reproduction in any medium, provided the original work is properly cited. 